\title{
乳牛に打ける脱脂乳中プロジェステロン濃度 測定值に及ぼす乳汁採取条件の影響
}

\author{
岡田啓司 ${ }^{1)}$ 佐藤 繁1) \\ 鈴木利行 ${ }^{1)}$ 金田義宏 ${ }^{2)}$ \\ (平成元年 12 月 7 日受付・平成 2 年 6 月 8 日受理)
}

\begin{abstract}
Effect of Collection Method on Skim Milk Progesterone Concentration in Cows Keiji Okada*, Shigeru Sato, Toshiyuki Suzuki and Yoshiniro Kaneda (* Veterinary Clinic and Training Center, Miyagi Prefectural Federation of Agricultural Mutual Aid Association, Kurokawa, Miyagi 981-36)
\end{abstract}

\section{SUMMARY}

The relationships between progesterone levels in skim milk and collection methods of samples were investigated. The progesterone levels in skim milk differed significantly from quarters and from collection times. The differences of mean progesterone concentration in intra-quarters were from $0.4 \mathrm{ng} / \mathrm{ml}$ to $1.7 \mathrm{ng} /$ $\mathrm{m} l$ at various collection times. Progesterone levels of before milk were significantly lower than those of bowl milk at morning milking in 4 cows, their plasma progesterone levels were over $5.0 \mathrm{ng} / \mathrm{ml}$. Although there were no significant differences between bowl milk, before milk and after milk in 6 cows, their plasma progesterone levels were under $5 \mathrm{ng} / \mathrm{ml}$. Progesterone levels in skim milk collected 4 hrs and 6 hrs after morning milking were significantly lower than those of bowl milk. Progesterone levels of skim milk were significantly lower than those of plasma, but positive correlation was recognized between both levels, except milk collected 6 hrs after milking._- Key Words : progesterone, skim milk, collection methods.

J. Jpn. Vet. Med. Assoc., 43, 650 654 (1990)

要

約

脱脂乳中のプロジェステロン (P) 測定を野外の臨床繁殖試験および検査に応用する目的で, 乳汁の採取条件と $\mathrm{P}$ 濃度の関係をEIA により検討した。

同一個体の 4 分房それぞれの脱脂乳中の $\mathrm{P}$ 濃度はいずれの採取時期においても差異がみられ，その幅は $0.4 \mathrm{ng} / \mathrm{m} l$ から $1.7 \mathrm{ng} / \mathrm{m} l$, 平均 $0.9 \mathrm{ng} / \mathrm{m} l$ であった. 乳汁の採取時期ごとの $\mathrm{P}$ 濃度は, 血漿中 $\mathrm{P}$ 濃度が高い群 ( $5 \mathrm{ng} / \mathrm{m} l$ 以 上）では混合乳に比べ朝の前搾り乳は有意に低い值を示したが，血漿中 $\mathrm{P}$ 濃度が $5 \mathrm{hg} / \mathrm{m} l$ 未満の群では朝の前搾り 乳，混合乳および後搾り乳間に有意の差は認められなかった．朝の搾乳後 2,4 および 6 時間目に採取した乳汁の脱 脂乳中 $\mathrm{P}$ 濃度は, 朝の混合乳と比べ搾乳後 4 および 6 時間には有意に低い值を示し, 特に $\mathrm{P}$ 濃度の高い例において 著明な低下が認められた．脱脂乳中の $\mathrm{P}$ 濃度は血漿中のそれと比べ，いずれの採取時期においても有意に低い值を示 したが，搾乳後 6 時間を除いて両者の間に有意の正の相関が認められた。なお $\mathrm{P}$ 濃度と乳成分との間に一定の関係は みられなかった。

以上のことから，脱脂乳中の $\mathrm{P}$ 測定を目的とした乳汁の採取は，その方法および時期を一定にすることが必要で， 混合乳を用いることが適当であると考えられた.

乳汁中のプロジェステロン（以下「P」と略す.）濃 度は血液中のそれと同様に変動し, 黄体機能を推定する

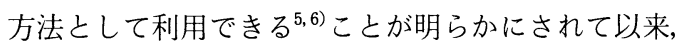
乳汁中の $\mathrm{P}$ 測定は乳牛の早期妊娠診断 $1,7,8,10,14,21)$, 発情

1) 宮城県農共連家畜診療研修所（黒川郡大衡村平林 38)

2) 岩手大学農学部（盛岡市上田 3-18)

Key Words：プロジェステロン, 脱脂乳, 採取条件.

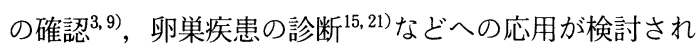
ている. 乳汁中 P の大部分は脂肪中に含まれる 全乳中の $\mathrm{P}$ 濃度は乳脂率の影響を受けて変動す $3^{2,4,6,19,20,21,23)}$. いっぽう脱脂乳中の $\mathrm{P}$ 濃度は乳脂率の 影響を受けないので乳汁の採取方法による差はなく，い つ, どの分房から乳汁を採取してもよい ${ }^{13,15)}$ とされてい るが，脱脂乳中 P 測定のための乳汁の採取条件につい て基礎的に検討した報告はあまり知られていない。

日獣会誌 $43 \quad 650 \sim 654 \quad(1990)$ 
岡田啓司 佐藤

著者らは，脱脂乳中の $\mathrm{P}$ 測定を野外臨床および $\mathrm{RI}$ 施 設を持たない臨床研究機関での臨床試験等に応用する目 的で, 乳汁の採取条件と EIA による $\mathrm{P}$ 濃度の関係を検 討した。

\section{材料および方法}

\section{供 試 牛}

供試牛は，2 戸の酪農家に飼養されている妊娠中期の ホルスタイン種乳牛 14 頭である。これらの牛はいずれ 屯臨床的に異常を認めず，その乳汁がカリフォルニア・ マスタイティス・テスト（以下「CMT」と略す.）変法 で陰性を示したものである，供試牛の産歴は $2 \sim 4$ (平 均 3.2) 産で， 1 日当たりの乳量は $15 \sim 28$ (平均 22) $\mathrm{kg}$ であった。 なお，これら 2 戸の酪農家の搾乳時刻は いずれも朝は午前 6 時頃, 夕方は午後 6 時頃であった.

\section{試料の採取および保存}

乳汁は, 朝の搾乳時にミルカーをつける前に手搾りし た前搾り乳，搾乳後バケットをよく攪はんしてから採取 した混合乳，およびミルカーをはずした直後に手搾りし た後搾り乳，さらに朝の搾乳終了後 2,4 および 6 時間 に手搾りで採取した乳汁である. No. 1〜 4 の 4 例では 混合乳以外はそれぞれ各分房ごとに約 $60 \mathrm{~m} l$ 採取し，他 の 10 頭（No. 5 〜 14）では，各分房からほぼ均等にな るように計 $60 \mathrm{~m} l$ を， $5 \sim 6$ 回の捨て搾りを実施した後 に採取した。採取した乳汁は直ちに氷水中で泠却し，一 部は $10 \mathrm{ml}$ の試験管に移し, $3,000 \mathrm{rpm}, 30$ 分間遠心し

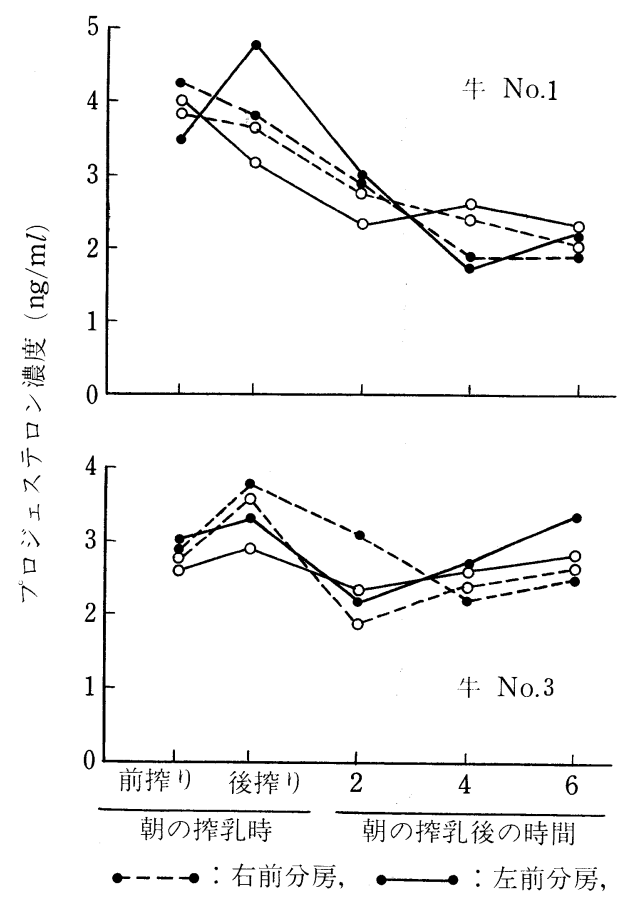

て脂肪層を除去し，得られた脱脂乳は別の小試験管に移 $し て-20^{\circ} \mathrm{C}$ に保存した。乳成分測定のための乳汁は $4{ }^{\circ} \mathrm{C}$ に保存した.

血液は朝の搾乳終了後 4 時間に, 頸静脈からへパリン 加真空採血管を用いて採取し，ただちに $3,000 \mathrm{rpm} ， 10$ 分間遠心して血漿を分離し, 得られた血漿はー $20^{\circ} \mathrm{C}$ に 保存した。

\section{脱脂乳および血漿中 $\mathbf{P}$ 濃度の測定}

$\mathrm{P}$ 濃度の測定は市販の EIA キット（P 測定 EIA キッ 卜「テイゾー」, 帝国臟器製薬）を用いて採取後 1 週間 以内に実施した。脱脂乳は測定直前に融解後, 安全性を 高めるため再度脱脂操作 $(3,000 \mathrm{rpm}, 30$ 分間遠心し上 層を除去）を実施し後，測定に供した。なお本キットの 測定内変動係数は $5.9 \sim 9.2 \%$, 測定間変動係数は $7.3 \sim$ $13.1 \%$ と小さく，二抗体法 EIA と高い相関のあること が証明されている ${ }^{16)}$.

\section{乳成分の測定}

乳成分の測定はいずれも採取した翌日に行った，乳脂 肪については 4 頭（No. 5〜8）でゲルベル氏法, 他の 10 頭で乳蛋白および乳糖などとともに自動測定装置 (MILKO SCAN 104, A/S N. Foss Electric, Denmark) を用いて測定した。

統 計 処 理

各数値間の有意差の検討は $\mathrm{t}$ 検定により, 相関は相関 分析により実施した.
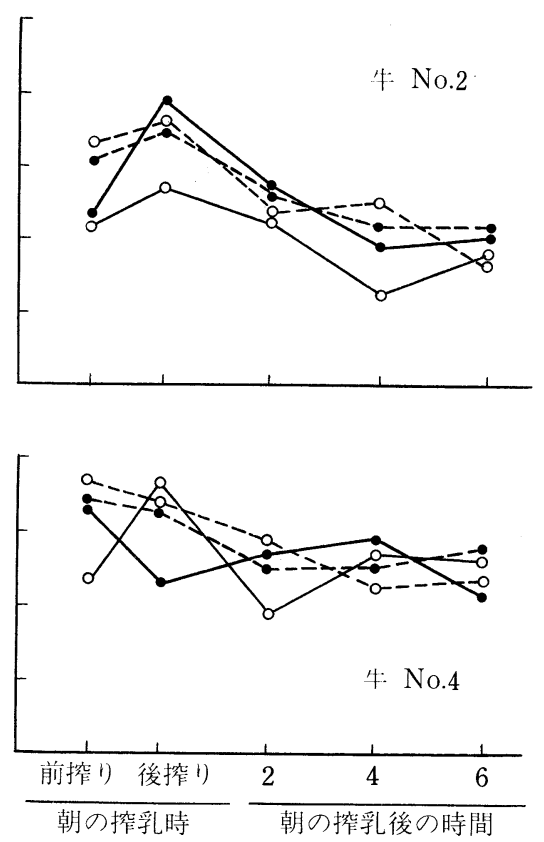

図 1 分房ごとの脱脂乳中プロジェステロン濃度 
乳牛における脱脂乳中プロジェステロン濃度測定值に及ぼす乳汁採取の影響

表 1 乳汁の採取時期ごとの脱脂乳中プロジェステロン濃度と乳成分

\begin{tabular}{|c|c|c|c|c|}
\hline 採 取 時 期 ${ }^{1)}$ & $\begin{array}{c}\text { プロジェステロン } \\
\text { 濃度 }(\mathrm{ng} / \mathrm{m} l)\end{array}$ & $\begin{array}{l}\text { 乳 } \begin{array}{c}\text { 脂 } \\
(\%)\end{array} \\
\text { 肪 }\end{array}$ & 乳 $\underset{(\%)}{\text { 蛋 }}$ 白 & 乳 $(\%)^{\text {糖 }}$ \\
\hline 前搾り & $2.7 \pm 0.5$ & $2.5 \pm 0.7^{* *}$ & $3.5 \pm 0.6$ & $4.6 \pm 0.4$ \\
\hline 混合乳 & $3.4 \pm 1.0$ & $4.2 \pm 0.5$ & $3.4 \pm 0.6$ & $4.6 \pm 0.3$ \\
\hline 後搾り & $3.2 \pm 1.5$ & $7.8 \pm 2.3^{* *}$ & $3.1 \pm 0.8$ & $4.4 \pm 0.3$ \\
\hline 搾乳後 2 時間 & $2.8 \pm 1.3$ & $6.7 \pm 1.8^{* *}$ & $3.1 \pm 0.7$ & $4.1 \pm 0.3$ \\
\hline 搾乳後 4 時間 & $2.3 \pm 0.9 *$ & $5.3 \pm 1.4^{*}$ & $3.1 \pm 0.6$ & $4.1 \pm 0.4$ \\
\hline 搾乳後 6 時間 & $2.2 \pm 0.8^{* *}$ & $3.9 \pm 1.1$ & $3.4 \pm 0.7$ & $4.0 \pm 0.7$ \\
\hline
\end{tabular}

1) 朝の搾乳時および搾乳後 $(\mathrm{n}=10$, Mean $\pm \mathrm{SD}) \quad *: \mathrm{p}<0.05, * *: \mathrm{p}<0.01$ (混合乳との有意 差）血漿中プロジェステロン濃度の平均: $4.1 \pm 1.3 \mathrm{ng} / \mathrm{ml}$

\section{成績}

\section{乳汁の採取分房と脱脂乳中 $\mathbf{P}$ 濃度}

乳汁を採取した分房ごとの脱脂乳中 $\mathrm{P}$ 濃度を図 1 に 示した.

分房ごとの $\mathrm{P}$ 濃度は 4 頭ともいずれの採取時期にお いても差異がみられ, 同一時刻の 4 分房の乳汁の $\mathrm{P}$ 濃 度の差は $0.4 \mathrm{ng} / \mathrm{ml}$ から $1.7 \mathrm{ng} / \mathrm{ml}$, 平均 $0.9 \mathrm{ng} / \mathrm{ml}$ で あった。な抒No. 2 では，搾乳後 6 時間までの間のいず れの採取時期においても左後分房乳の $\mathrm{P}$ 濃度はほかの 分房と比べ低い值で推移した. 4 分房の乳汁の平均 $\mathrm{P}$ 濃度は, 血漿中 $\mathrm{P}$ 濃度が $5 \mathrm{ng} / \mathrm{ml}$ 以上を示した No. 1 と 2 では搾乳後の時間の経過に伴い低下する傾向が認め られたが，血漿中 $\mathrm{P}$ 濃度が $5 \mathrm{ng} / \mathrm{m} l$ 未満の No. 3 と 4 ではほどんど変化が認められなかった。

\section{乳汁の採取時間之脱脂乳中 $\mathbf{P}$ 濃度}

乳汁の採取時期ごとの脱脂乳中 $\mathrm{P}$ 濃度を表 1 に示し た.

10 頭の平均值では，朝の前搾り乳は混合乳および後 搾り乳と比べやや低い值を示したが，3 者間で有意の差 は認められなかった。また搾乳後は $\mathrm{P}$ 濃度がしだいに 低下して，搾乳後 4 および 6 時間にはいずれも混合乳と 比べ有意に低い値を示した。

血漿中 $\mathrm{P}$ 濃度が $5 \mathrm{ng} / \mathrm{m} l$ 以上の 4 頭（A 群； 5.0 〜 $6.3 \mathrm{ng} / \mathrm{m} l$ ) と $5 \mathrm{ng} / \mathrm{m} l$ 未満の 6 頭（B 群； $2.4 \sim 3.7$ $\mathrm{ng} / \mathrm{m} l)$ に大別し，それぞれの群の採取時期ごとの脱 脂乳中の $\mathrm{P}$ 濃度を図 2 に示した。

A 群では混合乳の值に比べ前搾り乳は有意に低い値 を示したが，後搾り乳では差がみられず，また搾乳後の 時間の経過に伴い P 濃度の低下が著明に認められ，搾 乳後 4 および 6 時間には有意に低い值を示した。いっぽ うB 群では混合乳の值に比べ前搾り乳之後搾り乳では いずれ屯差がみられず，搾乳後 2 および 4 時間には有意 に低い值を示したが，搾乳後の時間の経過に伴う P 濃 度の変化は少なかった。しかし，搾乳後 6 時間には $1 \mathrm{ng} / \mathrm{m} l$ 前後の低値を示すむの屯認められた.

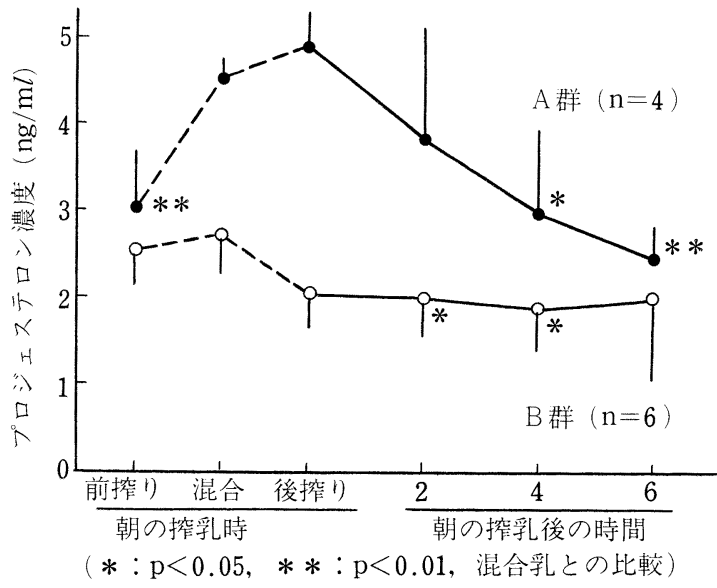

図 2 採取時期ごとの脱脂乳中プロジェステロン濃度

\section{乳成分之脱脂乳中 $\mathbf{P}$ 濃度の関係}

乳成分と脱脂乳中 $\mathrm{P}$ 濃度の関係は代表例を表 2 に示 した．分房ごとの乳脂率は各個体ともいずれの採取時期 に拀いても差異が認めら机，また 4 分房の平均值は搾乳 後の時間の経過にともない低下する傾向が認められた。 乳蛋白および乳糖は分房ごとに大きな差異はみられず， また乳成分と $\mathrm{P}$ 濃度の間に一定の関係は認められなか った.

乳汁の採取時期ごとの乳成分を表 1 に示した。乳脂率 は 10 頭の平均値では混合乳と比べ前搾り乳は有意に低 く，後搾り乳は有意に高い值を示した。また搾乳後 6 時 間までの間はしだいに低下したが， 2 および 4 時間には 混合乳と比べ有意に高い値を示した。

乳蛋白は採取時期による差はみられず，また乳糖は搾 乳後 2 時間に混合乳と比べ有意に低い值を示したほかは, 特に差異は認められなかった。なお $\mathrm{P}$ 濃度と乳脂率, 乳蛋白抢よび乳糖との間に有意の相関は認められなかっ た.

前記の血漿中 $\mathrm{P}$ 濃度が $5 \mathrm{ng} / \mathrm{ml}$ 以上の $\mathrm{A}$ 群と $5 \mathrm{ng} /$ $\mathrm{m} l$ 末満の $\mathrm{B}$ 群の乳脂率は図 3 に示すとおりいずれの採 取時期に㧈いてもほぼ同様の值であり, 両群の間に有意 の差は認められなかった。 
岡田啓司 佐藤 繁 鈴木利行, ほか

表 2 乳汁の分房ごとのプロジェステロン (P, $\mathrm{ng} / \mathrm{ml}$ ), 乳脂肪 ( $\mathrm{a}, \%)$, 乳蛋白 (b, \%), 乳糖 (c, \%) の濃度（牛 No. 1)

\begin{tabular}{|c|c|c|c|c|}
\hline \multirow{3}{*}{ 採 取 時 期 } & \multicolumn{2}{|c|}{ 前 } & \multicolumn{2}{|c|}{ 後 } \\
\hline & 左 & 右 & 左 & 右 \\
\hline & $\mathrm{P} / \mathrm{a} / \mathrm{b} / \mathrm{c}$ & $\mathrm{P} / \mathrm{a} / \mathrm{b} / \mathrm{c}$ & $\mathrm{P} / \mathrm{a} / \mathrm{b} / \mathrm{c}$ & $\mathrm{P} / \mathrm{a} / \mathrm{b} / \mathrm{c}$ \\
\hline 前搾り & 3.5/1.0/2.9/4. 7 & $4.3 / 1.7 / 2.9 / 4.6$ & 4. $0 / 1.3 / 2.9 / 4.7$ & $3.9 / 1.3 / 2.9 / 4.7$ \\
\hline 混合乳 & & (4. $1 / 3$ & $.9 / 4.6)$ & \\
\hline 後搾り & 4. $8 / 6.2 / 2.4 / 4.5$ & $3.8 / 6.6 / 2.6 / 4.3$ & 3. $2 / 6.2 / 2.7 / 4.4$ & $3.8 / 6.5 / 2.6 / 4.4$ \\
\hline 搾乳後 2 時間 & 3.0/6.1/2.5/4.3 & 2.9/6.0/2.6/4. 1 & 2. $3 / 6.5 / 2.5 / 4.2$ & $2.8 / 6.4 / 2.6 / 4.2$ \\
\hline 搾乳後 4 時間 & $1.7 / 5.6 / 2.6 / 4.3$ & 1. $9 / 4.9 / 2.6 / 4.0$ & 2. $6 / 4.8 / 2.6 / 4.2$ & 2. $4 / 4.6 / 2.7 / 4.3$ \\
\hline 搾乳後 6 時間 & 2. $2 / 3.8 / 2.7 / 4.4$ & 1. $9 / 3.4 / 2.6 / 4.1$ & 2. $3 / 3.1 / 2.7 / 4.4$ & 2. $1 / 3.2 / 2.7 / 4.4$ \\
\hline
\end{tabular}

表 3 脱脂乳中 $\mathrm{P}$ の血漿中 $\mathrm{P}$ に対する百分比および相関

\begin{tabular}{lcc}
\hline \hline 採 取 時 期 & 比率 $(\%)^{1)}$ & 相関係数 ${ }^{2)}$ \\
\hline 前搾り & $70 \pm 16$ & $0.633^{*}$ \\
混合乳 & $84 \pm 10$ & $0.621^{* *}$ \\
後搾り & $74 \pm 17$ & $0.951^{* *}$ \\
搾乳後 2 時間 & $66 \pm 16$ & $0.833^{* *}$ \\
搾乳後 4 時間 & $57 \pm 11$ & $0.840^{* *}$ \\
搾乳後 6 時間 & $55 \pm 20$ & 0.497 \\
\hline
\end{tabular}

1) (脱脂乳中 $\mathrm{P} /$ 血漿中 P) $\times 100 \quad 2$ ) 脱脂乳 中 $\mathrm{P}$ と血漿中 $\mathrm{P}$ の相関, $*: \mathrm{p}<0.05, * *: \mathrm{p}<0.01$

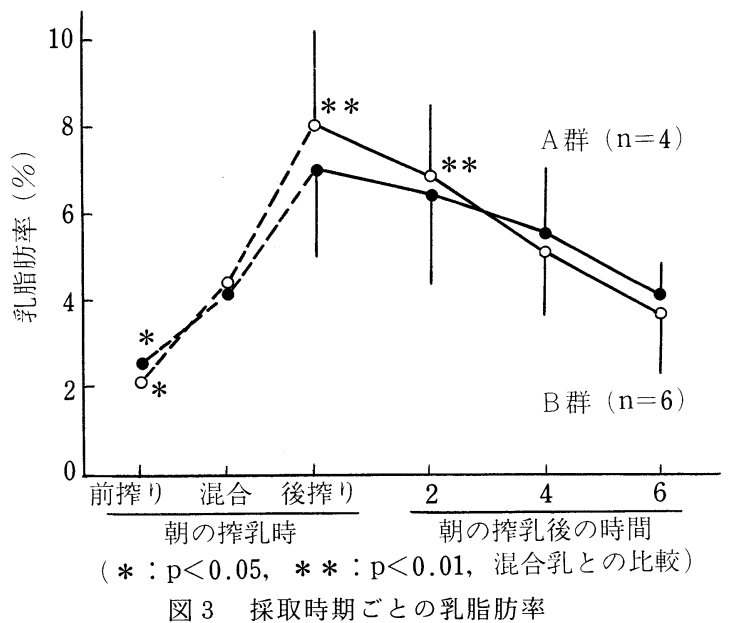

\section{脱脂乳中と血漿中 $\mathbf{P}$ 濃度の比較}

脱脂乳中と血漿中の $\mathrm{P}$ 濃度の関係は表 3 に示した。

脱脂乳中の $\mathrm{P}$ 濃度は, 血漿中の值にくらべいずれの 採取時期においても有意に低い值を示した．血漿中の $\mathrm{P}$ 濃度を $100 \%$ としたときの脱脂乳中の值は混合乳で最大 で, 平均 $84 \%$ であった，血漿中と脱脂乳中の $\mathrm{P}$ 濃度と の間に, 搾乳後 6 時間を除くほかの採取時期においてい ずれむ有意の正の相関が認められた。

\section{考察}

乳汁を採取した分房ごとの脱脂乳中 $\mathrm{P}$ 濃度は, 各個 体ともいずれの採取時期においても差異が認められた。
また，脱脂乳中 $\mathrm{P}$ 濃度と乳成分との間に一定の関係は 認められなかった。健康な乳房では分房ごとの乳汁に成 分の差がないことが知られている24). いっぽう乳房炎に 冒された乳汁では，カゼイン含量の減少や血液由来蛋白 の増加など乳成分に変化のあること ${ }^{11)}$ が知られている. 今回の供試牛はいずれの分房の乳汁す CMT 変法で陰性 であり，また乳脂肪以外は分房ごとの乳成分においてと くに差異がみられなかったことにより，臨床型乳房炎の 存在しないことが認められた。分房間における脱脂乳中 の $\mathrm{P}$ 濃度の差異についてはさらに例数を追加し, とく に潜在性乳房炎 ${ }^{11)}$ な゙との関連で検討する必要があると 考えられた。

乳汁の採取時期ごとの脱脂乳中 $\mathrm{P}$ 濃度は, 10 頭の平 均值では朝の前搾り乳, 混合乳および後搾り乳の間で有 意の差は認められず，搾乳後の時間の経過に伴いしだい に低下する傾向が認められた。血漿中 P 濃度が $5 \mathrm{ng} /$ $\mathrm{m} l$ 以上の $\mathrm{A}$ 群と, $5 \mathrm{ng} / \mathrm{m} l$ 未満の $\mathrm{B}$ 群で, 乳汁の採 取時期ごとの脱脂乳中 $\mathrm{P}$ 濃度を比較すると, 両群に㧍 いて異なる变化がみられた．特に A 群では混合乳の值 に比べ前搾り乳は有意に低い值を示し, 後搾り乳では差 がみられず，また搾乳後の時間の経過に伴い脱脂乳中 P 濃度は著明に低下する傾向か認められた。

MCCAUGHEY と GORDON ${ }^{13)}$ は, 発情期の牛 (96 例) と発情後 $21 \sim 22$ 日の牛（58 例）の前搾り乳, 混合乳 および後搾り乳の脱脂乳中の $\mathrm{P}$ 濃度を RIA 法で測定し た結果，分房間および採取時期間にいずれも有意の差が みられなかったと報告している。しかし，彼らの報告で 発情後 $21 \sim 22$ 日の混合乳の脱脂乳中 $\mathrm{P}$ 濃度の平均值 は $2.25 \mathrm{ng} / \mathrm{ml}$ と比較的低い值であった。

今回, $\mathrm{A}$ 群で認められた脱脂乳中 $\mathrm{P}$ 濃度の変化は乳 脂率の変化と同様の傾向を示した，全乳中の $\mathrm{P}$ 濃度は 前搾り乳では混合乳や後搾り乳と比べ有意に低い值を示 し, 混合乳と後搾り乳との間には差がみられないとの報 告 ${ }^{1920)}$ があり，また谷中ら ${ }^{23)}$ およびGINTHER ら ${ }^{4)}$ は，搾 乳終了後経時的に採取した全乳中の $\mathrm{P}$ 濃度がほぼ直線 的に低下し, 搾乳終了直後の值に対して 2 時間後以降有 意な低值を示したと報告している。これらの報告では， 
いずれも全乳中の P 濃度が乳脂率の影響で変動するこ とを示唆している.

乳汁中 P の大部分は脂肪に含まれる ${ }^{2,6)}$ ため, 脱脂乳 を用いる場合, 脱脂操作が重要であるが, いずれの方法 であ完全に脱脂することは困難 ${ }^{12}$ であることから, 乳脂 率の影響は無視できないと考えられる。しかしながら, 乳脂率は B 群であほぼ同様の值で推移し, また $\mathrm{P}$ 濃度 と乳脂率との間に有意の相関が認められなかったことな どから, 脱脂乳中の $\mathrm{P}$ 濃度に対する乳脂率の影響は不 明であった. 乳汁の採取時期と脱脂乳中 $\mathrm{P}$ 濃度の関係 については, 乳成分の影響あるいはほかの要因を含め, さらに検討する必要があると考えられた。

血漿中と脱脂乳中の $\mathrm{P}$ 濃度を比較検討した結果, 脱 脂乳中の值は血漿中のそれと比べいずれの採取時期にお いても有意に低い值を示した. しかし搾乳後 6 時間以外 は両者の間に有意の正の相関が認められた。 著者らは臨 床応用上最も採材しやすい時刻，すなわち朝の搾乳終了 後約 6 時間を経過した午前 11 時から正午の間に採取し た乳汁における脱脂乳中の P 濃度が血漿中と比べ著し く低い值を示し ${ }^{17)}$, 両者の間に有意の相関がみられない ことを認めている. また, 岸本ら ${ }^{10)}$ は乳汁の採取方法は 不明であるが, 脱脂乳中の $\mathrm{P}$ 測定による早期妊娠診断 の精度が血漿を用いた場合よりやや少ることを指摘して いる. ゆえに, 脱脂乳中 $\mathrm{P}$ 測定の臨床応用上乳汁の採 取方法は重要であり, 搾乳後 6 時間以上経過した時点で 採取した乳汁でのP 测定には問題があると考えられた.

以上のことから, 脱脂乳中の $\mathrm{P}$ 濃度は乳汁を採取す る分房および採取時期により差異のあることが認められ た. 脱脂乳中の $\mathrm{P}$ 測定を目的とした乳汁の採取はその 方法および時期を一定にすることが必要であり, 混合乳 を用いることが適当であると考えられた。

\section{引用文献}

1) Cox, N. M., Thompson, F. N., and Culver, D. H.: J. Dairy Sci., 61, 1616 1621 (1978).

2) Darling, J. A. B., Laing, A. H., and Harkness, R. A.,: J. Endocr., 62, 291 297 (1974).

3) Foulkes, J. A., Cookson, A. D., and Sauer, M. J.,
Vet. Rec., 111, 302 303 (1982).

4) Ginther, O. J., Nuti, L. C., Gorcia, M. C., and Tyler, W. J.,: J. Anim. Sci., 42, 155 159 (1976).

5) Heap, R. B., Gwyn, M., Laing, J. A., and Walters, D. E.,: J. Agr. Sci., 81, $151 \sim 157$ (1973).

6) Heap, R. B., Henville, A., and Linzell, J. L.,: J. Endocr., 66, 239 247 (1975).

7) Hoffmann, B., Gunzler, O., Hamburger, R., and Schmidt, W.,: Br. Vet. J., 132, 469 476 (1976).

8) Inaudi, P., Bacigalupo, M., Monitlola, C., et al.: J. Reprod. Fert., 65, 265 273 (1982).

9) Karg, H., Claus, R., Gunzier, O., et al.: Proc. 11 th. Int. Congr. on Diseases of Cattle, Tel-Aviv, 889 $\sim 894$ (1981).

10）岸本裕治, 加藤 寛, 三谷通博：日獣会誌，40, $161 \sim 164$ (1987).

11) Laitinen, J. T.: Br. Vet. J., 142, $562 \sim 568$ (1986).

12) Laitinen, J., Remes, E., Tenhunen, M., et al.: $B r$. Vet. J., 141, 297 307 (1985).

13) McCaughey, W. J., and Gordon, F. J.,: Br. Vet. J., $135,512 \sim 518$ (1979).

14) Nakao, T., Sugihashi, A., Ishibashi, Y., et al.: Theriogenology, 18, 267 274 (1982).

15) Nakao, T., Sugihashi, A., Saga, N., et al.: Am. J. Vet. Res., 44, 888 890 (1983).

16）及川大, 中尾敏彦, 森好政晴, ほか: 家畜繁殖誌, 33, $64 \sim 72$ (1987).

17）岡田啓司, 佐藤 繁, 鈴木利行：家畜診療, 320 , $43 \sim 46$ (1990).

18) Pennington, J. A., Spahr, S. L., and Lodge, J. R.,: J. Dairy Sci., 59, 1528 1531 (1976).

19) Pennington, J. A., Spahr, S. L., and Lodge, J. R.,: J. Dairy Sci., 64, 259 266 (1981).

20) Pope, G. S., Majzlik, I., Ball, P. J. H., and Leaver, J. D.,: Br. Vet. J., 132, $497 \sim 506$ (1976).

21) Singh, A., and Puthiyandy, R., J. Reprod. Fert., 59, 89 93 (1980).

22）高橋清治, 千葉正寛, 高橋英士, ほか：日獣会誌, 40, $241 \sim 246$ (1987).

23）谷中 匡, 井田京子, 佐々木捷彦, ほか：家畜繁殖 誌, 32, 63〜68 (1986).

24）全国乳質改善協会編集発行: 生乳成分の変動要因 と改善対策, 56〜62 (1979). 